\title{
PIGMENT CONTENT IN STRAWBERRY LEAVES (Fragaria sp.) EXPOSED TO DIFFERENT LIGHT QUALITY
}

\section{CONTENIDO DE PIGMENTOS EN HOJAS DE FRESA (Fragaria sp) EXPUESTAS A DIFERENTE CALIDAD DE LUZ}

\begin{abstract}
Fánor Casierra-Posada ${ }^{1}$, Jaime E. Peña-Olmos ${ }^{2}$, Esteban Zapata-Casierra ${ }^{3}$
${ }^{1}$ Agronomist, Ph.D. Universidad Pedagógica y Tecnológica de Colombia (UPTC), Faculty of Agricultural Sciences. Plant Ecophysiology Research Group. Avenida Central del Norte, Tunja, Colombia. Corresponding author: fanor.casierra@uptc.edu. co; ${ }^{2}$ Agronomist M.Sc. Secretaría de Educación de Bogotá. Plant Ecophysiology Research Group. E-mail: jaime.pena@uptc. edu.co; ${ }^{3}$ Student of Industrial Engineering. Universidad Tecnológica de Pereira - Risaralda, Colombia. E-mail: casierra1730@ hotmail.com
\end{abstract}

Rev. U.D.C.A Act. \& Div. Cient. 17(1): 87-94, Enero-Junio, 2014

\section{SUMMARY}

Light is a very important environmental factor which affects plant growth and development in various important ways. Not only quantity, but also quality is very essential in determining the plant growth. The influence of light quality on chlorophyll and carotenoid content of strawberry leaves was examined. Plants were grown in a greenhouse under differing light qualities provided by polypropylene filter film (control without colored cover, yellow, green, blue, transparent, and red). The treatments were laid out in a randomized design, each treatment was replicated ten times. The filter films were set $1 \mathrm{~m}$ above the crop canopy at the moment of transplanting and left until the end of the experiment. Eight months after transplanting both chlorophyll and carotenoid content in leaves were determined in alcoholic dilution using a spectrophotometer. The effect of different light qualities influenced chlorophyll content in leaves. The chlorophyll a content was highest in leaves under green and red light followed by blue, transparent and yellow light; the lowest chlorophyll a content was found in control plants. There were no differences in chlorophyll $b$ content. The carotene / chlorophyll ratio was highest in leaves developed without cover, and lowest in leaves under green and red light. Results indicate that the use of colored covers for provision of selective light quality may be a used for increasing strawberry production.

Key words: chlorophyll, carotene, light quality, color.

\section{RESUMEN}

La luz es un factor medioambiental trascendental que afecta el crecimiento y el desarrollo vegetal en varios aspectos importantes. No sólo la cantidad de luz, sino la calidad de la luz. Se examinó la influencia de la calidad de la luz sobre el contenido de clorofilas y de carotenos en hojas de fresa. Las plantas se cultivaron en invernadero bajo distintas calidades de luz proporcionadas por películas de polipropileno (control sin cobertura de color, amarillo, verde, azul transparente y rojo). Los tratamientos se dispusieron en un diseño aleatorizado con diez repeticiones. Las películas del filtro se colocaron $1 \mathrm{~m}$ por encima del cultivo, desde el momento del trasplante hasta el final del experimento. Ocho meses después del trasplante, el contenido de clorofila y de carotenos en las hojas se determinó por espectrofotometría en dilución alcohólica. Las diferentes calidades de luz influyeron sobre el contenido de clorofila. La concentración de clorofila a fue mayor en hojas desarrolladas bajo luz de color verde y rojo, seguida por la luz azul, transparente y amarilla. El más bajo contenido de clorofila a se encontró en las plantas control. No hubo diferencias en el contenido de clorofila $b$. La relación carotenos / clorofila fue mayor en hojas desarrolladas sin cobertura, y más baja en hojas bajo la luz verde y rojo. El uso de coberturas de colores para proporcionar una calidad de luz selectiva, podría ser una herramienta útil para aumentar la producción en fresa.

Palabras clave: clorofila, carotenos, calidad de la luz, color.

\section{INTRODUCTION}

Strawberry is an important crop in the cool highland regions of Colombia, being Cundinamarca, Antioquia and Norte de Santander the major producing departments. Both planted area and total production have increased greatly in Colombia in the past 20 years, reaching nationwide levels of 1135 ha and 45023t by 2011 (Agronet, 2012). 
Precision agriculture is a system-wide approach that seeks to optimize productive processes by using resources efficiently across agroecosystem variations in space and time. This optimization is agronomic, with the adjustment of cropping practices to plant needs; environmental, with the reduction of impacts related to agricultural activity; and economic, with the maximization of competitiveness through more efficient practices (Zhang et al. 2002; Leiva, 2008).

Along these lines, input use must be optimized in strawberry production systems in order to increase profit margins and assure higher competitiveness. Light quality is one of the production system factors than can be adjusted to better take advantage of inputs such as water or fertilizer.

Solar radiation is the energy source for photosynthesis by which plants produce the raw material for their growth and development. Part of this plant matter is harvested, either as fruit, leaves, stems or roots (Hernández et al. 2001). The quality of solar radiation, meaning the color of light received by plants may be an important element in the quest to increase production without increasing input use. As a point of reference, in the central Colombian high plains, small farmers growing strawberry with a 20-month cropping cycle spend $6.3 \%$ of total production costs on fertilizers and other soil amendments, while in Antioquia, this agricultural inputs reach $7.7 \%$ (Agronet, 2009).

Since, if photosynthetic efficiency was improved by exposing plants to light wavelengths that better plant behavior and favor fruit production, it would be possible to obtain higher yields with the same amount of inputs (Hernández et al. 2001; Patil et al. 2001; Casierra-Posada \& Rojas, 2009), or it might even be possible to decrease levels of inputs applied during the productive cycle.

Light quality has a determining effect on plant morphogenesis and pigments, and its effects have been used to commercial ends in horticultural plantations (Rajapakse \& Shahak, 2007). In the same way in radish, soybean, and wheat, light quantity and quality interact to determine plant morphology (Cope \& Bugbee, 2013), which is related to the growth and development of the plant, and these in turn with its production. In other studies with Fragaria sp., exposure to red light inhibited chlorophyll degradation in adult leaves (Nishiziwa et al. 1997). In plants of Triticum aestivum, formation of green pigments in plants was inhibited by red light, but this was reversed when plants were exposed to blue light or a mixture of blue and red light. Thus exposure to blue and red light caused plants to accumulate normal levels of carotenoids and chlorophyll pigments, as compared with plants exposed only to red or far-red light (Gupta \& Tripathy, 2010). In onion plants exposure to red light increased chlorophyll content in comparison with plants exposed to blue light and controls without colored light filters (Alam et al. 2007).

To determine whether light color affects the structure of photosynthetic antennae, Gussakovsky et al. (2007) exposed Pisum sativum plants to blue, red, or white light. Light color affected LHCII (Light Harvesting Complex II), and the authors have posited the existence of a long-term "memory" which affects LHCII sensitivity to current light color. Light quality strikes plant photosynthesis, since it alters photosynthetic apparatus activity and affects the Calvin-Benson cycle enzymes (Wang et al. 2009).

The existence of a sensitive color memory was also verified in a trial with Brassica oleracea var. Italica seeds that germinated under yellow, blue, orange, and transparent covers and were compared to plants grown in the open. During the nursery stage, seedlings grown under the red cover showed higher dry matter production as compared with other filter colors and the control treatment. Plants grown under blue cover revealed the lowest dry matter accumulation. The same trend was maintained even after plants were transplanted into open field conditions without colored covers (Casierra-Posada \& Rojas, 2009).

Farmers must be presented with cropping alternatives that improve yield. The use of colored covers for provision of selective light quality may be a useful tool in increasing strawberry production. Therefore the objective of the present study was the evaluation of the effect of different color covers on the content of photosynthetic pigments in greenhousegrown strawberry plants.

\section{MATERIALS AND METHODS}

The research was carried out in a glass greenhouse in Tunja, Colombia, located at $5^{\circ} 33^{\prime} 10.86^{\prime \prime} N$ latitude and $73^{\circ} 21^{\prime}$ 24.21" W longitude at an elevation of 2702 masl. Ten plants per treatment were exposed to solar radiation filtered through $15 \mu \mathrm{m}$ polypropylene films (suspended $1 \mathrm{~m}$ above plants) of different colors: red, yellow, blue, green, and transparent. Control plants grew in the greenhouse with no plastic film. Photosynthetical active radiation was determined with a lux meter 0500 (Testoterm Messtechnik, Lenzkirch, Germany); light reduction (opacity) under the plastic covers is displayed in table 1.

Strawberry plantlets (Fragaria sp. cv. Chandler) were used as planting material. These were kept at a temperature of $4^{\circ} \mathrm{C}$ $\pm 1^{\circ} \mathrm{C}$ for three weeks in order to break dormancy and thus achieve uniform sprouting, after which they were placed in $2 \mathrm{~L}$ capacity jars containing a nutrient solution with the following composition in $\mathrm{mg} \mathrm{L}^{-1}$ : nitrate nitrogen 40.3; ammonium nitrogen 4.0; phosphorus 20.4; potassium 50.6; calcium 
Table 1. Photosynthetically active radiation and opaqueness registered under different covers of polypropylene film

\begin{tabular}{|l|c|c|}
\hline \multirow{2}{*}{ Film color } & $\begin{array}{c}\text { Photosynthetically active } \\
\text { radiation (PAR) }\end{array}$ & $\begin{array}{c}\text { Opaqueness } \\
\text { (light reduction) }\end{array}$ \\
\cline { 2 - 3 } & $\left(\mu \mathrm{mol} \mathrm{m}^{-2} \mathrm{~s}^{-1}\right)$ & $(\%)$ \\
\hline Yellow & 152.34 & 49.25 \\
\hline Blue & 99.41 & 66.89 \\
\hline Red & 87.03 & 71.01 \\
\hline Green & 78.95 & 73.70 \\
\hline Transparent & 210.67 & 29.83 \\
\hline Control* & 300.24 & 0.00 \\
\hline
\end{tabular}

* without colored film

28.8; magnesium 11.4; sulfur 1.0; iron 1.12; manganese 0.112; copper 0.012 ; zinc 0.02264 ; boron 0.106 ; molybdenum 0.0012; cobalt 0.00036 .

Eight months after planting, entire plants were removed from the solution and the content of carotenoids and chlorophyll in leaves was determined by grinding leaves and extracting the pigments in a $70 \%$ ethanol solution. After filtering the solution, absorbance of the samples was analyzed in a Milton Roy Spectronic 401 spectrophotometer (Warminster, PA, USA), with wavelengths of 663,646 , and $470 \mathrm{~nm}$, according to the protocol reported by Steibung \& Fangmeier (1992).

The trial was organized in a completely randomized design, with the filter color as treatment variable. Each treatment consisted in ten plants, with each plant taken as an experi- mental unit. Results were subjected to a classical ANOVA test $(\mathrm{p}<0.05)$ and Tukey's range test using the PASW program (Predictive Analytics Software), version 18.0.0 (30-07-2009; IBM Corporation, Somers, USA).

\section{RESULTS AND DISCUSSION}

Levels of chlorophyll a showed highly significant differences in relation to film color. Maximum values for this pigment were obtained with green and red plastic film, giving values of 86.45 and $72.91 \%$ more chlorophyll a, respectively, than controls grown without colored film. On the other hand, the lowest values were found in plants grown under yellow, blue, and transparent films, though chlorophyll $a$ in these plants was higher (by $14.91,38.71$, and $37.81 \%$, respectively) than that in controls (Figure 1).

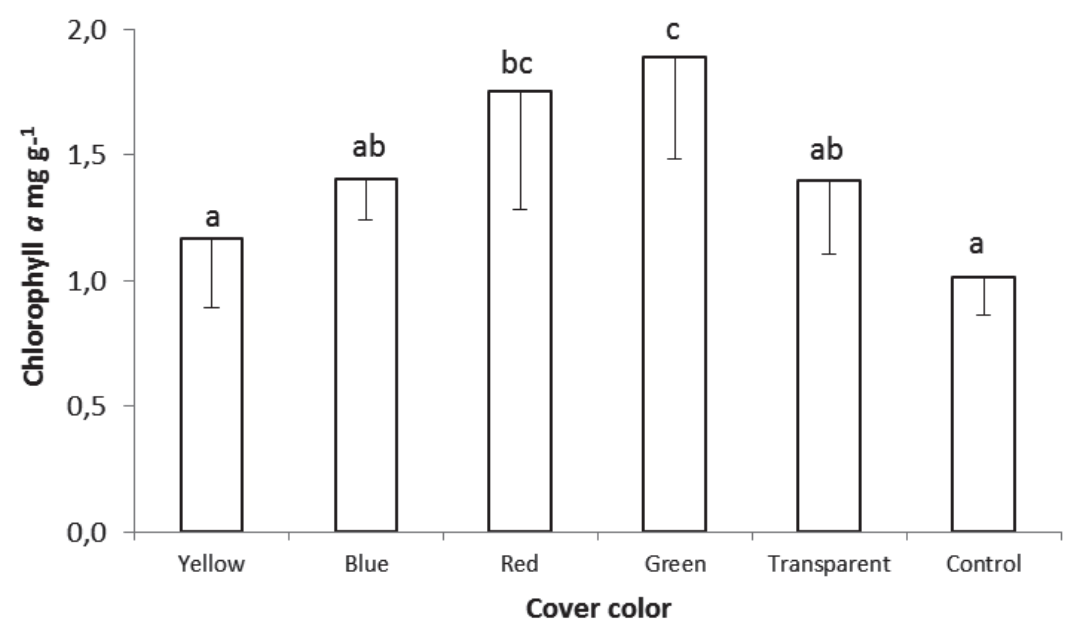

Figure 1. Chlorophyll a content in leaf tissue of strawberry plants grown under different plastic color film. 
In contrast to the present study, Alam et al. (2007) found that light quality had no significant effect on chlorophyll a content in onion plants (Allium cepa), but did affect chlorophyll $b$. For their part, Islam et al. (2000) reported results similar to the present study in Cattleya orchids. The authors detected that both red and blue light increased chlorophyll a content as compared to plants grown without colored film.

It is important to mention that the light wavelengths that affect photosynthesis are those that activate chlorophyll, while other wavelengths stimulate auxiliary pigments. Yellow-colored cryptochrome pigments help plants to track biological rhythms and respond to different wavelengths (Glime, 2007). Thus light quality can induce morphogenetic responses by exciting specific pigments. In addition to the well-documented effect of light quality in plants (Alam et al. 2007; Islam et al. 2000), in the conditions of the present study, the nature of the colored plastic films not only changed light quality but also gave different levels of shading, as shown in table 1. Hence shading apparently also played a role in plant responses to the different-colored films.

No significant differences between treatments were found in chlorophyll $b$ content. The significant differences found in total chlorophyll content obeyed the same proportions as chlorophyll a content, with red and green films presenting the highest values. Other colors and the control treatment showed lower values, following the same trend as for chlorophyll a (Figure 2). Plants exposed to red and green light contained 45.87 and $56.66 \%$ more chlorophyll than control plants grown with no plastic film, while plants grown under yellow, blue and transparent films were found to have 8.92, 21.54 , and $31.44 \%$ more chlorophyll than the control.

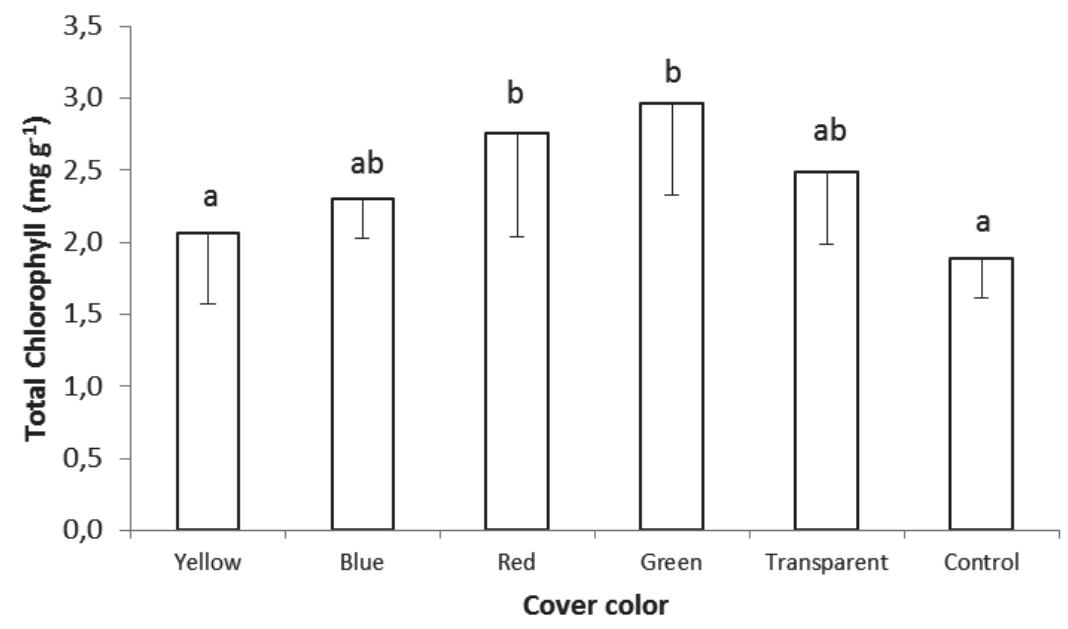

Figure 2. Total chlorophyll content in leaf tissue of strawberry plants grown under different plastic color film.

Miranda \& Williams (2007) found that in strawberry plants exposed to blue light, the total dry weight and total chlorophyll content increased, attributed to a high reaction rate of nonphotosynthetic photochemical processes under blue light. Wilson et al. (1998) discovered that in broccoli plants grown in vitro, red light increased dry weight and chlorophyll content of plantlets, while blue light reduced chlorophyll and led to elongated stems, but Jao et al. (2005) found higher chlorophyll content in Zantedeschia plantlets exposed to red + blue light, showing that blue light may be involved in chlorophyll development control.

The ratio of chlorophyll $a$ to chlorophyll $b$ was 51.19 and $52.40 \%$, higher, respectively, in plants growing under red and green films than in control plants. Under yellow, blue, and transparent films, the value of this ratio was $12.95,36.27$, and $10.90 \%$ higher, respectively, than in control plants grown with no colored plastic (Figure 3).

In shaded conditions, plants undergo modifications that help to overcome light limitation, such as higher chlorophyll content in reaction centers, and a high ratio of chlorophyll $b$ to chlorophyll a (Glime, 2007; Mc Donald, 2003). In addition, McDonald (2003) and Schopfer \& Brennicke (2006) mention that phytochrome may act as an indicator of the degree of shading in the leaves. With increased shading, both the red/ far-red ratio is reduced, as well as the $P_{\mathrm{fr}} / \mathrm{P}_{\text {total }}$ ratio. Given that light is enriched with far-red wavelengths in the shade, this tends to excite photosystem I (PSI) preferentially over PSII, and plants attend to invest resources in PSII (rich in chlorophyll $b$ ) as opposed to an equal increment in PSI and PSII. A higher total chlorophyll content was seen in the pres- 


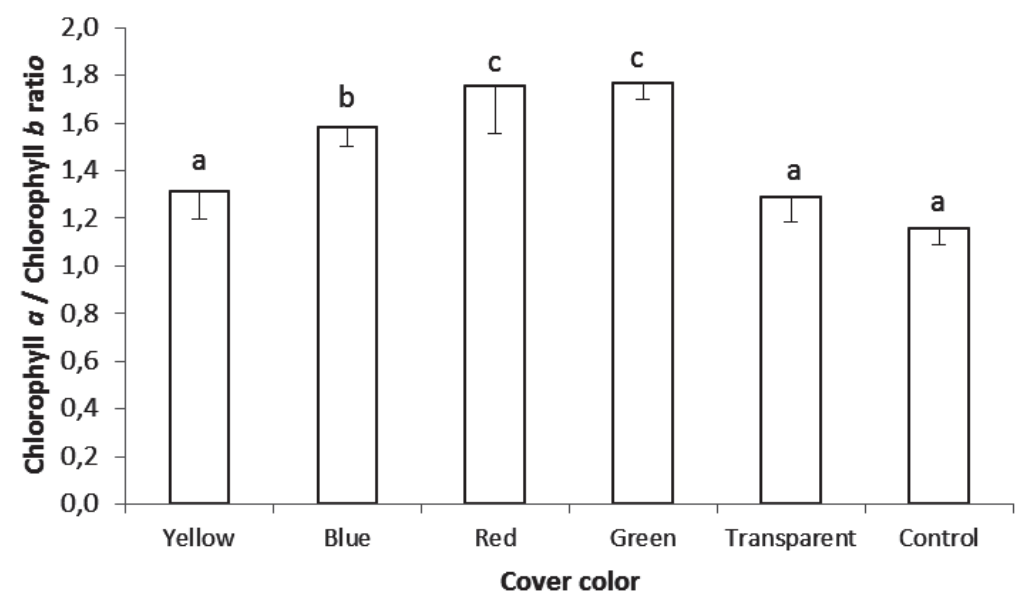

Figure 3. Ratio of chlorophyll $a$ to chlorophyll $b$ in leaf tissue of strawberry plants grown under different plastic color film.

ent study as a result of increases in chlorophyll $a$, but unlike results mentioned by Glime (2007) and McDonald (2003), the relationship between chlorophylls $a$ and $b$ and the content of chlorophyll $b$ showed a tendency contrary to the normal effect caused by plant shading.

Casierra-Posada \& Rojas (2009) used plastic films of different colors and with differing degrees of opacity to filter light for broccoli seedlings and detected morphogenetic differences among plantlets. This was attributed more to light quality than to opaqueness, since normally when shading increases so does leaf area, as reported by Francescangeli et al. (2007), but for Casierra-Posada \& Rojas (2009), leaf area decreased with the increased shading induced by colored films. Thus, without totally discounting the possibility that shading had a collateral effect on pigment content, it can be assumed that, at least in the present study light quality is responsible for pigment levels in strawberry plants.
Many authors report that the ratio of chlorophyll a to chlorophyll $b$ is higher in leaves of plants grown under full sun than in shade-grown plants (Johnson et al. 1982; Chartzoulakis et al. 1995; Lei \& Lechowicz, 1998; Souza \& Válio, 2003). This differs from the results obtained in the present study in that the treatments producing the highest values for this ratio were those which, suffered more opacity due to the polypropylene film. This suggests that in the present study, the response of strawberry plants in terms of the relationship between the two chlorophyll types was due to the morphogenetic adaptation brought about by light quality.

For the ratio carotenoids to total chlorophyll, highly significant differences were found among treatments, with the lowest values encountered in plants exposed to red and green lights, which gave ratios 41.00 and $44.84 \%$ below the value for control plants grown with no plastic cover. The ratios of carotenoids to total chlorophyll found in plants growing under yellow, blue, and transparent films were 12.77, 30.01, and $14.93 \%$ lower than in control plants (Figure 4).

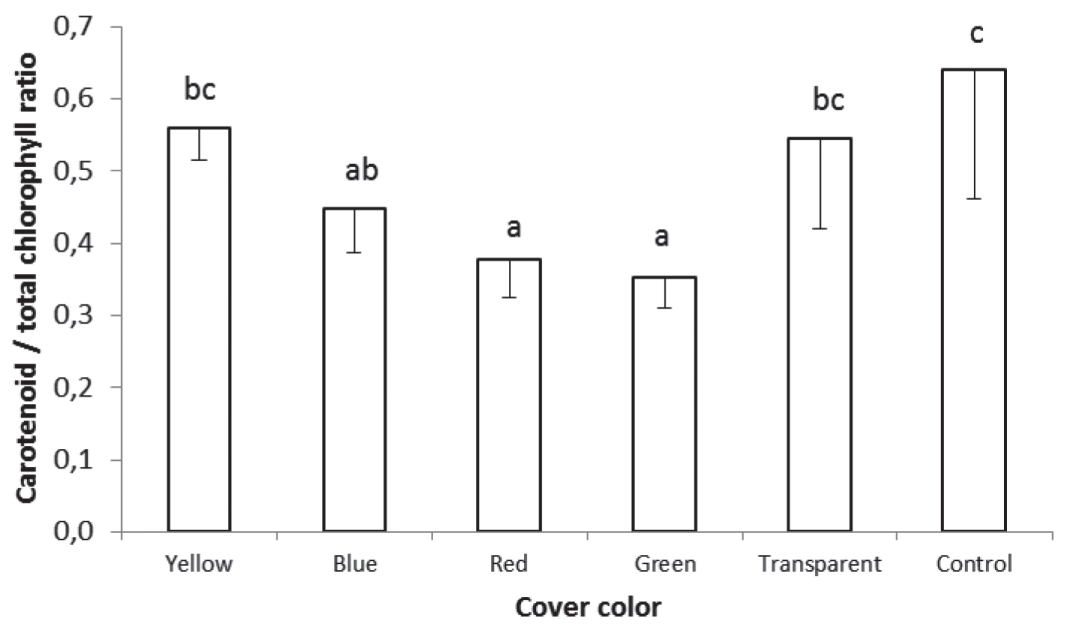

Figure 4. Ratio of carotenoids to total chlorophyll in leaf tissue of strawberry plants grown under different plastic color film. 
In the blue-green alga Spirulina platensis, light intensity and quality have been found to affect carotenoid content. In this species the highest carotenoid concentration was found when algae were exposed to white light with a photosynthetic photon flux of $432 \mu \mathrm{mol} \mathrm{m} \mathrm{m}^{-2}$. Beta-carotene and echinenone were the most abundant carotenoids under white light of high and low intensity; a algae exposure to red and blue light reduced myxoxanthophyll content (Olaizola \& Duerr, 1990).

Sánchez Saavedra \& Voltolina (2002) reported that relative growth efficiency of the diatoms Chaetoceros sp., Skeletonema costatum and Thalassiosira pseudonana were significantly higher at $210 \mu \mathrm{E} \mathrm{m}^{-2} \mathrm{~s}^{-1}$, under a mixture of blue and green light for Chaetoceros sp. and S. costatum and under white light for T. pseudonana. The chlorophyll content of the three species exposed only to blue-green light or blue-green light mixed with white light were significantly higher than with white light; in all cases, chlorophyll was lower under higher photon flux rates, while carotenoids showed the inverse tendency. In the present study, no statistically significant difference was found in carotenoid content in leaves, for which the difference presented in figure 4 corresponds to the variations in total chlorophyll content and not to a difference in carotenoid concentration.

Wallen \& Geen (1971), Rikvin (1989) and Senger (1987) described faster growth and higher protein and chlorophyll content in marine algae exposed to blue light as compared to those grown under white light. Nevertheless, other authors suggest that light intensity is more important than spectral composition and that after acclimation, plant responses depend on light quantity and not on quality (Gostan et al. 1986; Morel et al. 1987; Humbeck et al. 1988).

The blue and far-red portions of white light are known for their important function in genetic expression of plants and in morphogenesis (Senger \& Ruhl, 1980; Reymond et al. 1992; Kaufman, 1993; Short et al. 1994; Gupta \& Tripathy, 2010). In their time Borthwick et al. (1952) mentioned the fact that far-red wavelengths offer plants important information about their environment, despite this color range's relative inefficiency for photosynthesis. Generally the pigments that sense far-red light and the ratio of red to far-red drive aspects of molecular, biochemical, and morphological processes (Quail, 2002; Devlin et al. 2003; Chen et al. 2004; Casal \& Yanovsky, 2005). This is a demonstration of how light quality, despite often being unimportant for plant metabolism, can influence plant form, composition, and adaptive strategy to optimize light capture when light quality or quantity is unfavorable.

Conflict of interests: The manuscript was prepared and reviewed with the participation of the authors, who declare that there exists no conflict of interest that puts in risk the validity of the results presented. Funding: This study was supported by the Directorate of Research of the Pedagogical and Technological University of Colombia (UPTC) and the Administrative Department of Science, Technology, and Innovation of Colciencias, through the Young Researcher program. It followed the working priorities of the Plant Ecophysiology research group, part of the Agricultural Engineering program of the Faculty of Crop and Animal Sciences.

\section{BIBLIOGRAPHY}

1. AGRONET. 2009. Costos de producción por hectárea. SIPSA. Available in Internet: http://www.agronet.gov. co/www/htm3b/public/boletines/Costos2009trim1/ Agricolas/Cundiboyacense/EC\%20Fresa-mediano. pdf and in: http://www.agronet.gov.co/www/htm3b/ public/boletines/Costos2009trim1/Agricolas/Antioquia/EC\%20Fresa-peque\%C3\%B1o.pdf (accessed 01/12/2011).

2. AGRONET. 2012. Producción nacional por producto: Fresa. Report. Available in Internet: http://www. agronet.gov.co/agronetweb1/Estad\%C3\%ADsticas/ ReportesEstad\%C3\%ADsticos.aspx (accessed 29/08/2011).

3. ALAM, M.N.; ISLAM, M.S.; ALI, M.K.; BARKOTULLA, M.A.B.; KHANDAKER, S.M.A.T. 2007. Effect of light qualities on dry matter production, crop growth performance and chlorophyll content in onion plant. Res. J. Agr. Biol. Sci. 3(6):871-875.

4. BORTHWICK, H.A., HENDRICKS, S.B.; PARKER, M.W.; TOOLE, E.H.; TOOLE, V.K. 1952. A reversible photoreaction controlling seed germination. Proc. Natl. Acad. Sci. USA. 38:662-666.

5. CASAL, J.J.; YANOVSKY, M.J. 2005. Regulation of gene expression by light. Int. J. Developm. Biol. 49:501511.

6. CASIERRA-POSADA, F.; ROJAS, J.F. 2009. Efecto de la exposición del semillero a coberturas de colores sobre el desarrollo y productividad del brócoli (Brassica oleracea var. italica). Agr. Col. 27(1):49-55.

7. CHARTZOULAKIS, K.; THERIOS, I.; NOITSAKIS, B. 1995. Effects of shading on gas exchange specific leaf weight and chlorophyll content in four kiwifruit cultivars under field conditions. J. Hort. Sci. Ashford Kent. 68(4):605-611. 
8. CHEN, M.; CHORY, J.; FANKHAUSER, C. 2004. Light signal transduction in higher plants. Ann. Rev. Genetics. 38:87-117.

9. COPE, K.R.; BUGBEE, B. 2013. Spectral effects of three types of white light-emitting diodes on plant growth and development: absolute versus relative amounts of blue light. HortScience. 48(4):504-509

10. DEVLIN, P.F.; YANOVSKY, M.J.; KAY, S.A. 2003. A genomic analysis of the shade avoidance response in Arabidopsis. Plant Physiol. 133:1617-1629.

11. FRANCESCANGELI, N.; SANGIACOMO, M.A.; MARTÍ, H.R. 2007. Vegetative and reproductive plasticity of broccoli at three levels of incident photosynthetically active radiation. Span. J. Agric. Res. 5(3):389-401.

12. GLIME, J.M. 2007. Bryophyte Ecology. Physiological Ecology. Volume 1, Chapter 9: light. E-book sponsored by Michigan Technological University and the International Association of Bryologists. Available in Internet: http://www.bryoecol.mtu.edu/ (accessed 01/12/2010).

13. GUPTA, V.; TRIPATHY, B.C. 2010. Effect of light quality on chlorophyll accumulation and protein expression in wheat (Triticum aestivum L.) seedlings. Int. J. Biotechn. Biochem. 6(4):521-536.

14. GUSSAKOVSKY, E.E.; SHAHAK, Y.; SCHROEDER, D.F. 2007. Color of illumination during growth affects LHCII chiral macroaggregates in pea plant leaves. J. Photochem. Photobiol. B: Biology. 86:121-130.

15. GOSTAN, J.; LECHUGA-DEVEZE, C.; LAZZARRA, L. 1986. Does blue light affect the growth of Chaetoceros protuberans (Bacillariophyceae)? J. Phycol. 22:63-71.

16. HERNÁNDEZ, J.; ESCOBAR, I.; CASTILLA, N. 2001. La radiación solar en invernaderos mediterráneos. Horticultura Global: Rev. Industria, Distribución y Socioeconomía Hortícola. 157:18-27.

17. HUMBECK, K.; HOFFMAN, B.; SENGER, H. 1988. Influence of energy flux and quality of light on the molecular organization of the phytoplankton apparatus in Scenedesmus. Planta (Berl.). 173:205-212.

18. ISLAM, M.O.; MATSUI, S.; ICHIHASHI, S. 2000. Effect of light quality on carotenoid contents of in vitro growing seedling of Cattleya. J. Orchid Soc. India. 14(12):7-17.
19. JAO, R-C.; LAI, C-C.; FANG, W.; CHANG S-F. 2005. Effects of red light on the growth of Zantedeschia plantlets in vitro and tuber formation using lightemitting diodes. HortScience 40(2): 436-438.

20. JOHNSON, C.R.; NELL, T.A.; ROSENBAUM, S.E. 1982. Influence of light intensity and drought stress on $\mathrm{Fi}$ cus benjamina L. J. Am. Soc. Hort. Sci. Mount Vernon. 107(2):252-255.

21. KAUIFMAN, L.S. 1993. Transduction of blue-light signals. Plant Physiol. 102:333-337.

22. LEI, T.T.; LECHOWICZ, M.J. 1998. Diverse responses of maple saplings to forest light regimes. Ann. Bot. 82(1):9-19.

23. LEIVA, F. 2008. Agricultura de precisión en cultivos transitorios. Universidad Nacional de Colombia. 108p.

24. McDONALD, M.S. 2003. Photobiology of higher plants. John Wiley and Sons Ltd. p.113-147.

25. MIRANDA, J.H.; WILLIAMS, R. 2007. Developmental influence of in vitro light quality and carbon dioxide on photochemical efficiency of PS II of strawberry leaves (Fragaria x ananassa). J. Appl. Hort. 9(1):13-16.

26. MOREL, A.; LAZZARRA, L.; GOSTAN, G. 1987. Growth rate and quantum yield time response for a diatom to changing irradiances (energy and color). Limno. Oceanogr. 32:1066-1084.

27. NISHIZAWA, T.; SHISHIDO, Y.; KUMAKURA, H.; HAMAMOTO, H.; KUDO, M. 1997. Petiole length, chlorophyll and carbohydrate levels, and photosynthetic rates of june-bearing strawberry plants as influenced by red-light irradiation during storage under cool conditions. Sci. Hort. 72:25-33.

28. OLAIZOLA, M.; DUERR, E.O. 1990. Effects of light intensity and quality on the growth rate and photosynthetic pigment content of Spirulina platensis. J. Appl. Phys. 2(2):97-104.

29. PATIL, G.G.; OI, R.; GISSINGER, A.; MOE, R. 2001. Plant morphology is affected by light quality selective plastic films and alternating day and night temperature. Gartenbauwissenschaft. 66(2):53-60.

30. QUAIL, P.H. 2002. Phytochrome photosensory signalling networks. Nature Rev. Mol. Cell Biol. 3:85-93. 
31. RAJAPAKSE, N.C.; SHAHAK, Y. 2007. Light-quality manipulation by horticulture industry. En: Whitelam, G.C.; Halliday, K.J. (eds). Light and plant development. Blackwell Publ. Oxford, UK. p.290-312.

32. REYMOND, P.; SHORT, T.W.; BRIGGS, W.R.; POFF, K.L. 1992. Light-induced phosphorylation of a membrane protein plays an early role in signal transduction for phototropism in Arabidopsis thaliana. Proc. Nat. Acad. Sci. USA 89:4718-4721.

33. RIKVIN, R.B. 1989. Influence of irradiance and spetral quality on the carbon metabolism of phytoplankton. I. Photosynthesis, chemical composition and growth. Mar. Ecol. Proc. Ser. 55:291-294.

34. SÁNCHEZ-SAAVEDRA, M.P.; VOLTOLINA, D. 2002. Effect of photon fluence rates of white and blue-green light on growth efficiency and pigment content of three diatom species in batch cultures. Cienc. Mar. 28(3):273-279.

35. SCHOPFER, P.; BRENNICKE, A. 2006. Das Blatt als photosynthetisches System. In: Schopfer, P.; Brennicke, A. (eds). Pflanzenphysiologie Elsevier $\mathrm{GmbH}$, Spektrum Akademischer Verlag. Heidelberg. p. 255278.

36. SENGER, H.; RUHL, D. 1980. The influence of pentachlorophenol on the biosynthesis of 5-aminolevulinic acid and chlorophyll. Int J. Biochem. 12:1045-1048.

37. SENGER, H. 1987. Blue light responses: phenomena and occurrence in plants and microorganisms. CREC Press Inc. Boca Raton. Vol. I. p.160; Vol II. p.169.

38. SHORT, T.W.; PORST, M.; PALMER, J.; FERNBACH, E.; BRIGGS, W.R. 1994. Blue Light Induces Phosphory- lation at Seryl Residues on a Pea (Pisum sativum L.) Plasma Membrane Protein. Plant Physiol. 104:13171324.

39. SOUZA, R.P.; VÁLIO, I.F.M. 2003. Leaf optical properties as affected by shade in saplings of six tropical tree species differing in successional status. Braz. J. Physiol. 15(1):49-54.

40. STEIBUING, L.; FANGMEIER, A. 1992. Pflanzenökologisches Praktikum. UTB für Wissenschaft. Eugen Ulmer Verlag. Stuttgart. p.180-182.

41. WALLEN, D.G.; GEEN, G.H. 1971. Light quality in relation to growth, photosynthetic rates and carbon metabolism in two species of marine plankton algae. Mar. Biol. 10:34-43.

42. WANG, H.; GU, M.; CUI, J.; SHI, K.; ZHOU, Y.; YU, J. 2009. Effects of light quality on $\mathrm{CO}_{2}$ assimilation, chlorophyll fluorescence quenching, expression of Calvin cycle genes and carbohydrate accumulation in Cucumis sativus. J. Photochem. Photobiol. B. 96:30-37.

43. WILSON, S.B.; IWABUCHI, K.; RAJAPAKSE, N.; YOUNG, R.E. 1998. Responses of broccoli seedlings to light quality during low-temperature storage in vitro: I. Morphology and survival. Hort. Sci. 33(7):12531257.

44. ZHANG, N.; WANG, M.; WANG, N. 2002. Precision agriculture: a worldwide overview. Comp. Electron. Agricult. 36:113-132.

Received: 27 May 2013

Accepted: 14 January 2014

Como citar:

Casierra-Posada, F.; Peña-Olmos, J.E.; Zapata-Casierra, E. 2014. pigment content in strawberry leaves (Fragaria sp.) exposed to different light quality. Rev. U.D.C.A Act. \& Div. Cient. 17(1): 87-94. 